\title{
Bullous keratopathy: a study of endothelial cell morphology in patients undergoing cataract surgery
}

\author{
A K BATES AND H CHENG \\ From the Eye Hospital, Walton Street, Oxford OX2 6AN
}

SUmmary Preoperative and postoperative endothelial cell morphology was examined in three types of patients participating in a randomised, controlled trial of cataract surgery. The first sustained modest endothelial cell loss and served as controls, the second and third sustained high cell loss, but only the latter progressed to bullous keratopathy. The technique of examining endothelial cell morphology is described and its validity assessed. Measures of cell area, number of sides, side length, and variation in cell size and cell shape were utilised. No significant differences were found between the three groups by any of the preoperative morphological measures. Furthermore, postoperative values of variation in cell shape and cell size did not differ significantly between the groups. No evidence was found in our patients to support the hypothesis that eyes at particular risk of developing bullous keratopathy may be differentiated on the basis of their preoperative or early postoperative endothelial cell morphology.

Bullous keratopathy has become the commonest condition requiring penetrating keratoplasty. ${ }^{22}$ The increase in incidence of bullous keratopathy may have resulted from the increased volume of cataract surgery, new surgical techniques, or increased implantation of intraocular lenses of varying design. The exact contribution of each potential cause has not been determined, but a better understanding is desirable to identify vulnerable cases and risk factors. Much emphasis has been placed recently on the morphology of the corneal endothelium, ${ }^{3}$ and a suggestion has been made that eyes developing bullous keratopathy may have more preoperative polymorphism or pleomorphism. The purpose of this paper is to report on an examination of endothelial cell morphology pre- and postoperatively of eyes developing bullous keratopathy and compare that to findings in controls.

\section{Material and methods}

Patients studied were participating in a randomised controlled trial of cataract surgery which has been in progress for six years, for five of which there was no loss to follow-up except through death. Detailed accounts of the trial design and surgical techniques have already been reported. ${ }^{+}$The majority of Correspondence to Hung Cheng, FRCS. patients were treated by one experienced surgeon who contributed 274 eyes of 268 patients with a mean age of 72 years and a range of 55-89 years. All the patients in the present study on bullous keratopathy contributed only one eye in the study and had only one eye operated on at the time of this assessment. Patients were randomised into one of three treatment groups which were:

Group $A$. Intracapsular extraction followed by contact lens fitting.

Group B. Intracapsular extraction and implantation of an iris supported lens-Federov I.

Group C. Extracapsular extraction and implantation of a Binkhorst two-loop iridocapsular lens.

Patients had endothelial cell photographs taken preoperatively, at one month, six months, and yearly after surgery. Cell densities were derived in all patients by a counting method which masks the patients' identity. The method of photography ${ }^{5}$ and precision estimates ${ }^{6}$ have been reported.

A detailed protocol and structured follow-up enabled us to identify three groups of patients. The first group were patients who underwent uneventful surgery and postoperative recovery and who sustained only modest endothelial cell loss (mean cell loss six months after operation $=10.03 \%$, $\mathrm{SD}=6 \cdot 56 \%)$. This group served as controls. The second group were patients whose surgery and/or 
postoperative recovery was complicated and who sustained large cell loss in the early postoperative period but did not develop bullous keratopathy (mean cell loss six months after operation $=33.66 \%$, $\mathrm{SD}=18 \cdot 2 \%$ ). The third group sustained large endothelial cell loss and developed bullous keratopathy (mean cell loss six months after operation $=31 \cdot 68 \%$, $\mathrm{SD}=16 \cdot 9 \%)$.

Preoperative and one month postoperative endothelial cell photographs from these three groups of patients were enlarged to allow analysis of cell morphology. The original magnification factor of 148 times was increased to 311 times and photographic contrast enhancement techniques were used in developing the film. The apices of the endothelial cells were then digitised on a Summagraphics MM 1201 digitising pad with a digitising pen and the data analysed by an IBM personal computer. Digitisation in this context means the characterisation of points by a set of numbers. The digitising tablet employed was able to determine the location of points $\pm 0.625 \mathrm{~mm}$ with repeatability for the same point of $\pm 0.25 \mathrm{~mm}$ or better (manufacturers' specification). For most photographs 75 cells were digitised and in others a minimum of 50 cells. Evidence for the adequacy of a 50-cell sample has been presented by Bourne. ${ }^{7}$

A program was developed which, from digitisation of the apices of endothelial cells, will compute the area of individual cells, that of the smallest and largest cells, a range of cell areas, side lengths and the number of sides, and the perimeter of each cell. From these basic data two further measures were computed. As an index of variation in cell area the coefficient of variation was calculated by dividing the standard deviation of the cell area by the mean cell area and then expressing this as a percentage. This ratio is independent of cell size and provides a quantitative measurement of variation in cell area (polymegathism). Variation in cell shape was quantified by comparing the digitised cells with equilateral hexagons. For an equilateral hexagon the ratio of area:perimeter ${ }^{2}$ is a constant ( $\sin 60^{\circ} / 12$ or 0.07217 ). The deviation of digitised cells from hexagonality may be expressed as a percentage according to the equation $\left[\left(\mathrm{A} / \mathrm{p}^{2}\right) / 0 \cdot 07217\right] \times 100$, such that, if the cell is an equilateral hexagon, the index will be 100 . This value is a dimensionless expression of variation in cell shape (pleomorphism) which is independent of size and orientation. ${ }^{8}$

\section{VALIDATION OF DIGITISATION TECHNIQUE}

To test the accuracy of the computerised digitisation, 50 hexagons of calculated area (confirmed by weighing) were digitised five times.

To estimate precision, 50 endothelial cells from two specular microscopic photographs were digitised
Table 1 Validation study

\begin{tabular}{lll}
\hline $\begin{array}{l}\text { Digitisation } \\
\text { procedure }\end{array}$ & \multicolumn{2}{l}{ Mean cell area of } \\
\cline { 2 - 3 } & Large cells & Small cells \\
\hline 50 Cells from 2 & $287 \cdot 85 \pm 2 \cdot 9$ & $134 \cdot 10 \pm 1 \cdot 8$ \\
photos five times & $\mathrm{SD}=1 \cdot 0 \%$ of mean & $\mathrm{SD}=1 \cdot 3 \%$ of mcan \\
3Central photos of 2 & $292 \cdot 93 \pm 3 \cdot 4$ & $119 \cdot 33 \pm 1 \cdot 9$ \\
patients & $\mathrm{SD}=1 \cdot 2 \%$ of mean & $\mathrm{SD}=1 \cdot 6 \%$ of mean \\
\hline
\end{tabular}

five times, one with a population of large cells and the other small cells. Thus five mean cell areas were obtained for each photograph.

Reproducibility was examined by digitising three specular microphotographs of the central corneal endothelium from two patients, again one with large and the other with small endothelial cells.

\section{Results}

The validation study showed a high degree of accuracy, precision, and reproducibility. Accuracy: the mean value of digitising 50 hexagons of calculated area five times differed from the calculated area by only $3 \cdot 15 \%$. Precision: repeated digitisation of 50 cells from a sample of large and a sample of small cells produced a standard deviation of 1.0 and $1.3 \%$ of the mean (Table 1). As expected, the value was smaller for large cells. The mean cell area could be measured with a precision of $1.15 \%$ by this technique. Reproducibility: the variation of mean cell area between the three photographs of the same patient was about $1 \cdot 2-1 \cdot 6 \%$ (Table 1 ).

The results of the morphological analysis of preoperative photographs from the three groups of eyes are shown in Table 2. There was no significant difference in the values of the different features except for mean cell area. The mean area of the smallest cells in eyes developing bullous keratopathy was significantly larger, probably through inclusion of two eyes with low cell density.

One month postoperatively, as expected, the values of all the features examined were significantly greater in the two groups, with high cell loss in comparison with the control group. However, neither coefficient of variation nor deviation from hexagonality showed any significant change. In a few patients the photographs were not of good enough quality for digitisation.

\section{Discussion}

The validation study showed a high degree of accuracy, precision, and reproducibility. Our results on precision and reproducibility compare very favourably with those reported by others. ${ }^{q-11}$ 
Table 2 Morphological analysis of preoperative photographs

\begin{tabular}{|c|c|c|c|}
\hline & $\begin{array}{l}\text { Controls } \\
n=15\end{array}$ & $\begin{array}{l}\text { High cell loss, } \\
\text { patients } n=7\end{array}$ & $\begin{array}{l}\text { Bullous } \\
\text { keratopathy, } \\
\text { patients } n=9\end{array}$ \\
\hline Mean cell area & $\begin{array}{l}427 \cdot 66 \\
S D=75 \cdot 56\end{array}$ & $\begin{array}{l}430 \cdot 94 \\
S D=53 \cdot 66\end{array}$ & $\begin{array}{l}494 \cdot 75 t \\
S D=104 \cdot 39\end{array}$ \\
\hline Mean cell density & $\begin{array}{l}2802 \\
S D=356\end{array}$ & $\begin{array}{l}2534 \\
S D=410\end{array}$ & $\begin{array}{l}2483 \\
S D=490\end{array}$ \\
\hline $\begin{array}{l}\text { Mean area of } \\
\text { smallest cell }\end{array}$ & $\begin{array}{l}180 \cdot 71 \\
S D=33 \cdot 87\end{array}$ & $\begin{array}{l}170 \cdot 81 \\
\mathrm{SD}=23 \cdot 59\end{array}$ & $\begin{array}{l}233 \cdot 82^{*} \\
\mathrm{SD}=61 \cdot 51\end{array}$ \\
\hline $\begin{array}{l}\text { Mean area of } \\
\text { largest cell }\end{array}$ & $\begin{array}{l}855 \cdot 08 \\
S D=176 \cdot 88\end{array}$ & $\begin{array}{l}865 \cdot 76 \\
S D=212 \cdot 10\end{array}$ & $\begin{array}{l}933 \cdot 59 \\
S D=221 \cdot 94\end{array}$ \\
\hline $\begin{array}{l}\text { Mean no. of sides } \\
\text { per cell }\end{array}$ & $\begin{array}{l}6 \cdot 01 \\
S D=0 \cdot 14\end{array}$ & $\begin{array}{l}5 \cdot 87 \\
\mathrm{SD}=0 \cdot 10\end{array}$ & $\begin{array}{l}6 \cdot 00 \\
S D=0.09\end{array}$ \\
\hline Mean side length & $\begin{array}{l}13 \cdot 07 \\
\mathrm{SD}=1 \cdot 05\end{array}$ & $\begin{array}{l}13.53 \\
S D=0.96\end{array}$ & $\begin{array}{l}14 \cdot 16 \\
S D=1 \cdot 42\end{array}$ \\
\hline $\begin{array}{l}\text { Coefficient of } \\
\text { variation }\end{array}$ & $\begin{array}{l}31 \cdot 09 \\
\mathrm{SD}=6 \cdot 71\end{array}$ & $\begin{array}{l}30.41 \\
S D=5.95\end{array}$ & $\begin{array}{l}28 \cdot 58 \\
\mathrm{SD}=4 \cdot 13\end{array}$ \\
\hline $\begin{array}{r}\text { Deviation from } \\
\text { hexagonality }\end{array}$ & $\begin{array}{l}92.98 \\
\mathrm{SD}=1.43\end{array}$ & $\begin{array}{l}92 \cdot 26 \\
\mathrm{SD}=0 \cdot 90\end{array}$ & $\begin{array}{l}93 \cdot 51 \\
\mathrm{SD}=1 \cdot 21\end{array}$ \\
\hline Cell density ranges & 1333 & 1186 & 1260 \\
\hline
\end{tabular}

Areas in $\mu \mathrm{m}^{2}$; density in cells $/ \mathrm{mm}^{2}$; length in $\mu \mathrm{m}$.

${ }^{*} \mathrm{p}=0.05$ vs controls. $\dagger$ No significant difference from controls.

Preoperative assessment of endothelial cell morphology showed values for mean cell area consistent with typical endothelial cell densities for this age group of patients (for example, for controls= 2338 cells $\left./ \mathrm{mm}^{2}\right){ }^{12}$ Hexagons were the most commonly observed cell shape as shown by the mean number of sides-close to six observed in each group (Fig. 1). The values for the coefficient of variation were within the range previously quoted for patients obtained before cataract surgery ${ }^{3}$ and suggest that

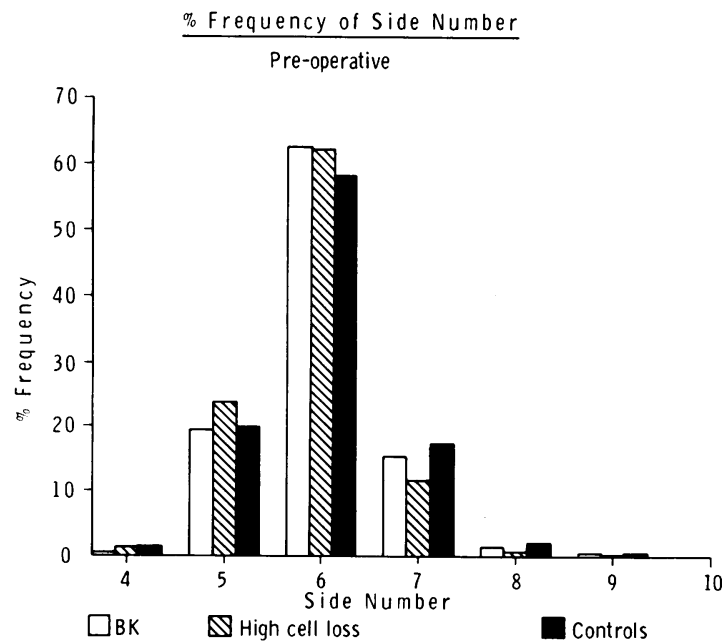

Fig. 1 Frequency distribution of the number of sides of the cells in the three groups of eyes before operation. cells were relatively uniform in size. Similarly values for deviation from hexagonality were all very high, suggesting homogeneity of cell shape.

Interestingly there was no significant difference between the three groups on any of the preoperative morphological measures studied except mean area of the smallest cell area between controls and bullous keratopathy $(\mathrm{BK})$ patients. This is due to the fact that two of the eyes with BK had a preoperative density of $<2000$ cells $/ \mathrm{mm}^{2}$. It has been suggested that cellular polymegathism and pleomorphism reflect susceptibility to surgical trauma ${ }^{1314}$ and in particular postoperative corneal oedema. ${ }^{3}$ However, our results suggest that for eyes without pre-existing disease preoperative endothelial morphology does not differentiate either patients who will undergo large endothelial cell losses or those who will progress to bullous keratopathy from controls.

Postoperative analysis of endothelial cell morphology revealed expected increases in mean cell area as well as area of the smallest and the largest cells in all groups, with the appearance of cells with the greater number of sides in the high cell loss groups (Table 3 and Fig. 2). However, while cells increased in size, the fairly constant values for coefficient of variation and deviation from hexagonality suggest that in general they increased uniformly, so that variation in size and shape between cells changed little. It is just possible that at one month after surgery central cellular rearrange-

Table 3 Morphological analysis of postoperative photographs

\begin{tabular}{|c|c|c|c|}
\hline & $\begin{array}{l}\text { Controls } \\
n=12\end{array}$ & $\begin{array}{l}\text { High cell loss, } \\
\text { patients } n=6\end{array}$ & $\begin{array}{l}\text { Bullous } \\
\text { keratopathy, } \\
\text { patients } n=5\end{array}$ \\
\hline Mean cell area & $\begin{array}{l}498 \cdot 20 \\
S D=64 \cdot 03\end{array}$ & $\begin{array}{l}923 \cdot 03^{* * *} \\
\mathrm{SD}=232 \cdot 46\end{array}$ & $\begin{array}{l}885 \cdot 83^{* * *} \\
\mathrm{SD}=56 \cdot 52\end{array}$ \\
\hline Mean cell density & $\begin{array}{l}2436 \\
S D=269\end{array}$ & $\begin{array}{l}1294 \\
\mathrm{SD}=212\end{array}$ & $\begin{array}{l}1602 \\
S D=69\end{array}$ \\
\hline $\begin{array}{l}\text { Mean area of } \\
\text { smallest cell }\end{array}$ & $\begin{array}{l}244 \cdot 06 \\
S D=65 \cdot 35\end{array}$ & $\begin{array}{l}383 \cdot 26^{*} \\
\mathrm{SD}=141 \cdot 58\end{array}$ & $\begin{array}{l}432 \cdot 34^{* * *} \\
S D=90 \cdot 08\end{array}$ \\
\hline $\begin{array}{l}\text { Mean area of } \\
\text { largest cell }\end{array}$ & $\begin{array}{l}926 \cdot 46 \\
S D=120 \cdot 01\end{array}$ & $\begin{array}{l}1792 \cdot 09 * * * \\
\mathrm{SD}=510 \cdot 34\end{array}$ & $\begin{array}{l}1529 \cdot 30^{* * *} \\
\mathrm{SD}=186 \cdot 03\end{array}$ \\
\hline $\begin{array}{l}\text { Mean no. of sides } \\
\text { per cell }\end{array}$ & $\begin{array}{l}5 \cdot 97 \\
S D=0 \cdot 10\end{array}$ & $\begin{array}{l}6 \cdot 21^{*} \\
\mathrm{SD}=0 \cdot 22\end{array}$ & $\begin{array}{l}6.07^{*} \\
S D=0.05\end{array}$ \\
\hline Mean side length & $\begin{array}{l}14 \cdot 31 \\
S D=0 \cdot 86\end{array}$ & $\begin{array}{l}18 \cdot 61^{* * *} \\
S D=2 \cdot 56\end{array}$ & $\begin{array}{l}18 \cdot 86^{* * *} \\
S D=0 \cdot 49\end{array}$ \\
\hline $\begin{array}{l}\text { Coefficient of } \\
\text { variation }\end{array}$ & $\begin{array}{l}28 \cdot 55 \\
S D=3 \cdot 58\end{array}$ & $\begin{array}{l}31 \cdot 39 \dagger \\
\mathrm{SD}=5 \cdot 01\end{array}$ & $\begin{array}{l}26 \cdot 28 \dagger \\
\mathrm{SD}=1 \cdot 95\end{array}$ \\
\hline $\begin{array}{r}\text { Deviation from } \\
\text { hexagonality }\end{array}$ & $\begin{array}{l}92 \cdot 37 \\
\mathrm{SD}=1 \cdot 21\end{array}$ & $\begin{array}{l}92.55 \dagger \\
S D=1.47\end{array}$ & $\begin{array}{l}92 \cdot 19 \dagger \\
\mathrm{SD}=2 \cdot 51\end{array}$ \\
\hline Cell density ranges & 707 & 551 & 133 \\
\hline \multicolumn{4}{|c|}{$\begin{array}{l}\text { Areas in } \mu \mathrm{m}^{2} ; \text { density in cells } / \mathrm{mm}^{2} ; \text { length in } \mu \mathrm{m} . \\
{ }^{* * *} \mathrm{p}<0.001 \\
\left.{ }^{* *} \begin{array}{l}\mathrm{p}<0.01 \\
\mathrm{p}<0.05\end{array}\right\} \text { vs controls. }+ \text { No significant difference from controls. }\end{array}$} \\
\hline
\end{tabular}




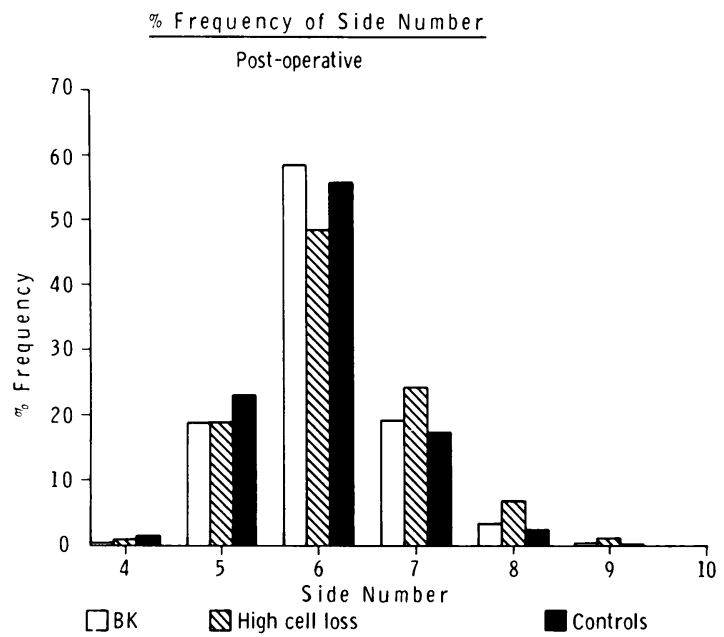

Fig. 2 Frequency distribution of the number of sides of the cells from the same eyes as in Fig. 1 one month after operation.

ment to compensate for cell loss may not have been completed, but this should not happen to the same degree in all three groups. It is of interest that patients who later developed corneal decompensation did not show significantly greater polymegathism or cellular pleomorphism than either controls or other patients with high cell loss.

In conclusion, our results do not support the hypothesis that patients undergoing cataract surgery who are at particular risk of developing postoperative bullous keratopathy may be differentiated on the basis of their preoperative or early postoperative endothelial cell morphology. We believe that any single measure of the corneal endothelium, whether it be of cell density or morphology, has limited potential as a predictor of outcome. Data from this study presented elsewhere suggest that the development of bullous keratopathy after cataract surgery may best be predicted by careful longitudinal observation of rate of endothelial cell loss. ${ }^{15}$
This study was supported by the National Eye Institute Grant No. EY 02677-06. We thank Celia Tagari for writing the digitisation program, Linda Wood for helping with the digitisation and preparing the paper, and Don Barbour for the photographic work.

\section{References}

1 Taylor DM, Atlas BF, Romanchuk KG, Stern AL. Pseudophakic bullous keratopathy. Ophthalmology 1983; 90: 19-24.

2 Smith RE, McDonald HR, Nesburn AB, Minckler DS. Penetrating keratoplasty: changing indications, 1947-1978. Arch Ophthalmol 1980; 98: 1226-9.

3 Rao G, Aquavella J, Goldberg S, Berk S. Pseudophakic bullous keratopathy: relationship to pre-operative corneal endothelial status. Ophthalmology 1984; 91: 1135-40.

4 Oxford Cataract Treatment and Evaluation Team. I. Cataract surgery: interim results and complications of a randomised controlled trial. Br J Ophthalmol 1986; 70: 402-10.

5 Price NC, Cheng H. Contact and non-contact specular microscopy. Br J Ophthalmol 1981; 65: 568-74.

6 Cheng H, Jacobs PM, McPherson K, Noble MJ. Precision of cell density estimates and endothelial cell loss with age. Arch Ophthalmol 1985; 103: 1478-81.

7 Bourne WM. Morphologic and functional evaluation of the endothelium of transplanted human cornea. Trans Am Ophthalmol Soc 1983; 81: 403-50.

8 Alanko $\mathrm{H}$. Microcomputer analysis for corneal endothelial cell morphology. Acta Ophthalmol (Kbh) 1983; 61: 229-39.

9 Sawa M, Tanishima T. The morphometry of the human corneal endothelium and follow up of postoperative changes. Jpn J Ophthalmol 1979; 23: 337-50.

10 Waring GO, Krohn MA, Ford GE, Harris RR, Rosenblatt LS. Four methods of measuring human corneal endothelial cells from specular micrographs. Arch Ophthalmol 1980; 98: 848-55.

11 Stefanson A, Mueller O, Sundmacher R. Non-contact specular microscopy of the normal corneal endothelium; a statistical evaluation of morphometric parameters. Graefes Arch Klin Exp Ophthalmol 1982; 218: 200-5.

12 Oxford Cataract Treatment and Evaluation Team. III. Long term corneal endothelial cell loss after cataract surgery. Arch Ophthalmol 1986; 104: 1170-5.

13 Bourne WM, Brubaker RF, O'Fallon M. Use of air to decrease endothelial cell loss during intraocular lens implantation. Arch Ophthalmol 1979; 97: 1473-5.

14 Schultz RD, Matsuda M, Yee RW, Edelhauser HF, Schultz KJ. Corneal endothelial changes in type I and type II diabetes mellitus. Am J Ophthalmol 1984; 98: 401-10.

15 Bates AK, Cheng H, Hiorns RW. Pseudophakic bullous keratopathy: relationship with endothelial cell density and use of a predictive cell loss model. Curr Eye Res 1986; 5: 363-6.

Accepted for publication 30 March 1987. 